\title{
Corrigendum: Challenges facing small business retailers in selected South African townships
}

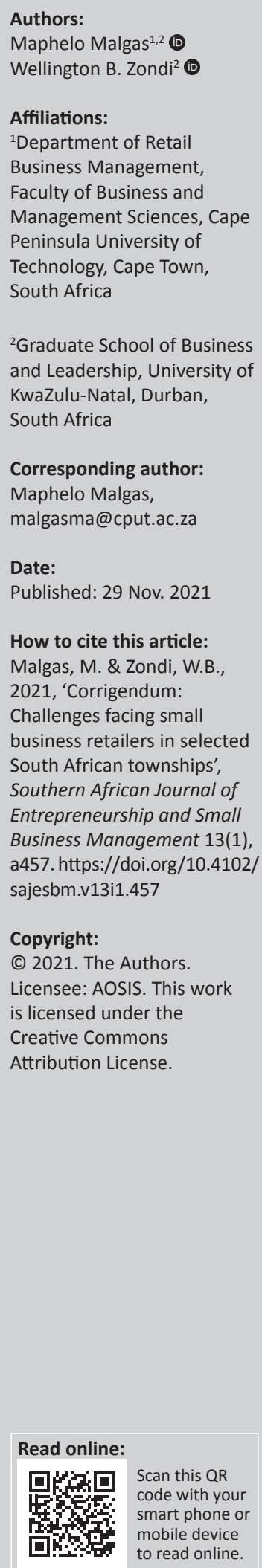

Scan this $Q R$ code with your smart phone or mobile device to read online.

In the version of this article initially published, Malgas, M. \& Zondi, W.B., 2020, 'Challenges facing small business retailers in selected South African townships', Southern African Journal of Entrepreneurship and Small Business Management 12(1), a202. https://doi.org/10.4102/sajesbm. v12i1.202, the first author's second affiliation was omitted in the 'Authors' and 'Affiliations' sections. The following affiliation should be added as his second affiliation: Graduate School of Business and Leadership, University of KwaZulu-Natal, Durban, South Africa.

This correction does not alter the study's findings of significance or overall interpretation of the study's results. The authors apologise for any inconvenience caused. 


\section{Challenges facing small business retailers in selected South African townships}

\begin{tabular}{|c|c|}
\hline \multicolumn{2}{|c|}{$\begin{array}{l}\text { Authors: } \\
\text { Maphelo Malgas }{ }^{1} \\
\text { Wellington B. Zondi }\end{array}$} \\
\hline \multicolumn{2}{|c|}{$\begin{array}{l}\text { Affiliations: } \\
{ }^{1} \text { Department of Retail } \\
\text { Business Management, } \\
\text { Faculty of Business and } \\
\text { Management Sciences, Cape } \\
\text { Peninsula University of } \\
\text { Technology, Cape Town, } \\
\text { South Africa }\end{array}$} \\
\hline \multicolumn{2}{|c|}{$\begin{array}{l}{ }^{2} \text { Graduate School of Business } \\
\text { and Leadership, University of } \\
\text { KwaZulu-Natal, Durban, } \\
\text { South Africa }\end{array}$} \\
\hline \multicolumn{2}{|c|}{$\begin{array}{l}\text { Corresponding author: } \\
\text { Maphelo Malgas, } \\
\text { malgasma@cput.ac.za }\end{array}$} \\
\hline \multicolumn{2}{|c|}{$\begin{array}{l}\text { Dates: } \\
\text { Received: } 12 \text { July } 2018 \\
\text { Accepted: } 21 \text { Nov. } 2019 \\
\text { Published: } 25 \text { Feb. } 2020\end{array}$} \\
\hline \multicolumn{2}{|c|}{$\begin{array}{l}\text { How to cite this article: } \\
\text { Malgas, M. \& Zondi, W.B., } \\
2020, \text { 'Challenges facing } \\
\text { small business retailers in } \\
\text { selected South African } \\
\text { townships', Southern African } \\
\text { Journal of Entrepreneurship } \\
\text { and Small Business } \\
\text { Management } 12(1) \text {, a202. } \\
\text { https://doi.org/10.4102/ } \\
\text { sajesbm.v12i1.202 }\end{array}$} \\
\hline \multicolumn{2}{|c|}{$\begin{array}{l}\text { Copyright: } \\
\text { (C) 2020. The Authors. } \\
\text { Licensee: AOSIS. This } \\
\text { is licensed under the } \\
\text { Creative Commons } \\
\text { Attribution License. }\end{array}$} \\
\hline \multicolumn{2}{|c|}{ Read online: } \\
\hline 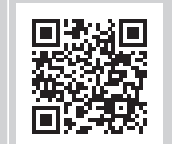 & $\begin{array}{l}\text { Scan this } Q R \\
\text { code with your } \\
\text { smart phone or } \\
\text { mobile device } \\
\text { to read online. }\end{array}$ \\
\hline
\end{tabular}

Background: South African townships have a vibrant small retailing business which at some point was dominated by local traders. However, in recent times, the country has attracted migrants who are very competitive in the township retailing space.

Aim: This study seeks to identify the challenges facing local small business retailers in the township retailing environments and then develop a business intervention model for traders to improve.

Setting: Primary research was conducted in two townships of Cape Town - Delft and Eindhoven.

Methods: The population of the study comprised two groups, namely, South African and foreign national small business retailers operating grocery retailer stores. The first group consisted of 55 South African small business retailers while the second group consisted of 75 migrant small business retailers. A random sample was targeted from each group and the quantitative research methodology was used in this study using a structured questionnaire with close-ended questions as a research instrument.

Results: The results showed growth of foreign national retailers and decline in the number of the local retailers in the two townships. The study showed that migrant retailers have a competitive edge over local retailers. The study also revealed that most local traders have a lower level of education compared to their migrant trader counterparts.

Conclusion: The local small business retailer requires targeted support from the government as suggested in the business intervention model proposed in this study.

Keywords: small business retailers; township retailing; migrant small business; migrant entrepreneurship; South African townships.

\section{Introduction}

The South African economy has a very large micro-enterprise sector, comprising both formal and informal businesses, and it provides a good environment for entrepreneurial development and advancement. This study focusses on the informal micro-enterprises who are small retailers in the township environment. Since the post-democratic dispensation of 1994 in South Africa, the government has encouraged small business development through various legislation. According to Herrington, Kew and Mwanga (2017) in the Global Entrepreneurship Monitor (GEM) report, South Africa has low levels of entrepreneurial activity relative to other countries participating in the GEM survey.

In South Africa, most of the activities of the micro-enterprises operate in the untaxed, unregulated informal economy. As the South African formal economy is unable to absorb the rising number of new entrants into the labour market every year, it often leads to economically active citizens pursuing micro-enterprises in the informal sector of the economy (Rolfe et al. 2010).

According to Liedeman (2013), since 2005, there has been significant rivalry between South African spaza shop operators and migrants who also operate spaza shops. Migrant traders use social systems and have access to cheap labour; application of contractual arrangements by their social connections, with their leaders administering their strategic investments and business deals in different locations have given them a competitive edge (Liedeman 2013). Migrant traders purchase as a collective in order to secure discounts and use the economies of scale to assist each other micro-financially by organising investments and business connections (Liedeman 2013). Competition and competitiveness in township retailing environments is about customers' buying power and their preferences (Ntema \& Marais 2010). 
Ntema and Marais (2010) further noted that:

Local informal traders are perceived to practise better customer service than their foreign counterparts. This finding counters an alleged notion by South Africans that non-South Africans are usually more professional in their attitude and business conduct than their South African counterparts and that they are thus able to attract more support from customers. (p. 8)

The aim of this paper is to understand the challenges and constraints facing local traders and the difference between the local and migrant traders in terms of trading capabilities. It would make sense to examine challenges and opportunities of South African small business retailers in township retailing environments. In this paper, a business intervention model for South African traders in this sector is proposed in order for the South African trader to compete meaningfully. The paper addresses the following objectives:

- To investigate the challenges and constraints facing South African small business retailers in township retailing environments.

- To develop a business intervention model for South African small business retailers to improve their competitiveness in township retailing.

\section{Literature review}

\section{The South African township retailing environment}

According to Ligthelm (2008):

... the pre-1994 retail landscape in the township areas was dominated by small, mainly informal retail businesses offering basic products and services to a relatively low-income consumer market. These businesses served as convenience shops to primarily lower income groups and attracted only a small portion of the consumer spending in township areas. (p. 37)

Most economically active people in township environments used urban shopping centres for their main shopping activities and used informal small business stores in the townships as convenience stores (Ligthelm 2008). Small business retailers play a critical role in the economy, but in the township environment small business retailers struggle to operate in the complex and competitive business environment (Cant \& Wiid 2013:713). Consumers have more options and small business retailers need to rethink their business model and begin to look at new ways of doing business (Cant \& Wiid 2013). This view is consistent with the 2004 DTI policy review, which noted that high levels of competition in retailing are identified as a critical problem for all categories of retail.

It must be noted that before 1994, small business retailers were mainly South Africans but after 1994 there has been a surge in the number of foreign nationals residing in South African townships (Ligthelm 2003).

This resulted in foreign nationals entering the small business retailing market initially as a means for survival and as they excelled in the small business retailing, the South African small business retailer began to struggle for survival. It is important for local traders to survive because one study showed that South African small business retailers employ fellow South Africans while foreign national retailers employ foreign nationals (Ntema \& Marais 2010). Whenever small foreign national business retailers employ another foreign national, it becomes a lost opportunity for the South African economy to reduce structural unemployment.

Ligthelm (2003) argues that:

... the informal sector plays an important and controversial role. While it offers opportunities for the unemployed, jobs in this sector tend to be low-paid, with little job security. Moreover, entrepreneurial activity is promoted, but at the price of noncompliance in respect of tax, labour and other regulations. (p. 55)

As indicated above, the small retailers who are the subject of this study are in the informal sector.

Ardyan (2016:83) defined business success 'as performance which is a true measure of success and success being visible from human resource performance, operational performance, marketing and financial performance'. Furthermore, the author noted that in order to improve performance, small businesses need to be able to 'track competitor's strategy, understand market trends and be responsive to the everchanging market conditions' (Ardyan 2016:91). However, customers of small business retailers in the township environment are more likely to find what they are looking for in a spaza shop owned by foreign national retailer than at a spaza shop owned by the South African small business retailer (Ntema \& Marais 2010).

Furthermore, the authors noted that customers expressed very high levels of dissatisfaction with the quality of products sold by foreign national small business retailers. Cant and Wiid (2013) noted that South African small business retailers need training and workshops to enhance their knowledge base and skills. The authors also noted that small business retailers need to have associations and representative bodies that will focus on crime prevention and also negotiate with the South African government for any required assistance. According to Ligthelm (2003), it is crucial for small retailers to maintain sufficient stock levels, as this reduces the need to replenish stocks more than once a week. Furthermore, the author noted that small business retailers also struggle to keep competitive prices and end up taking small loans from informal lenders. Small business retailers struggle with the marketing of their own products, while they themselves rely on promotional material, such as store pamphlets, to decide about where they will buy a particular product (Ligthelm 2003).

Brijlal and Jere (2019) noted that entrepreneurship is central to reducing the high unemployment rates among women in South Africa. The authors further noted that women starting their own businesses have been designated as the new engines for growth of the developing economies such as South Africa.

However, Danish et al. (2019) observed that an entrepreneurial culture is central for developing economies as it reflects the 
attitude, values, skills and power of a group or individuals working in an institute or an organisation to generate income. Furthermore, the authors noted that entrepreneurial culture and innovation are two of the most important elements for the growth and success of developing countries. According to Herrington et al. (2017), although the ratio of male to female participation in early-stage entrepreneurial activities vary considerably across the total sample of GEM countries, reflecting differences in culture and customs regarding female participation in the economy, a consistent finding is that men are more likely to be involved in entrepreneurial activities.

The South African government is not creating an environment that is conducive for small businesses to create jobs (Adisa, Abdulraheem \& Mordi 2014). The authors further noted that the South African government should strengthen the service offerings of its development finance agencies to make sure that they provide seminars, workshops and training for small business owners on how to run a successful small business.

This is consistent with the views of Döckel and Ligthelm (2005:54) who argued that considerable emphasis should be placed on the contribution that the small, medium and microenterprise (SMME) sector can make towards relieving the high levels of high unemployment in South Africa. It must be noted that since the 1995 white paper on small business development in 1995, the National Small Business Act (102 of 1996) was enacted in South Africa, and it was amended in 2004. In 2014, a special South African government ministry of small business development was established to nurture the growth and development of small businesses in South Africa.

\section{Competition and competitiveness among small business retailers}

Competition and competitiveness in the township retailing environments is about customers' buying power, business retailers preferences and understanding the consumer behaviour of the poor township dwellers (Ntema \& Marais 2010). Herrington, Kew and Kew (2008) cited by Antonites and Kliphuis (2011:2) stated that:

For businesses to become competitive, develop relationships with customers and suppliers and have easier access to businessrelated information, it is important that they have access to technology as well as have the capacity to use it effectively.

Porter (2008:85) observed that 'rivalry among existing competitors takes many familiar forms, including price discounting, new product introductions, advertising campaigns, and service improvements. High rivalry limits the profitability of an industry'. South African small business retailer's incapacity to keep enough stock forces customers to buy from foreign national traders even if they view foreign national traders to have inferior quality stock (Ntema \& Marais 2010). Furthermore, Ntema and Marais (2010) observed that:

South African traders feel they have been left unaided when dealing with the consequences of unfair competition resulting from the alleged failure by their own government to regulate the influx of non-South African traders. (p. 22)
As regards the Cape Town Metropolitan by-laws controlling informal small business retailers, some small business associations in the city view these by-laws as being biased towards the small business retailers and favourable to national retailers entering the township market. These associations view the by-laws as unrealistic for the spaza shops and geared towards creating an enabling environment for the development of shopping malls where national retailers thrive (Battersby, Marshak \& Mngqibisa 2017). The presence of migrants in the township small business retailing sector is viewed by the South African small business retailers as illegal, and they view migrant small business retailers as people who have an agenda to oust them from this market segment (Ntema \& Marais 2010). Furthermore, the authors noted that the South African small business retailers also argue that migrant retailers practice unfair business models such as selling expired goods, fake goods and/or inferior products that are not suitable for consumption.

\section{Porter (2008) noted that:}

Competition on dimensions other than price i.e. on product features, support services, delivery time, or brand image, for instance is less likely to erode profitability because it improves customer value and can support higher prices. (p. 86)

Some South Africans who used to be retailers themselves have resorted to also renting out their business premises to migrant traders (Ntema \& Mais, 2010). Furthermore, the authors noted that migrant traders have competitive prices that benefit consumers. Strydom (2015:466) noted that 'heightened levels of competition between informal businesses and formal businesses has a major negative effect on the business survival of the informal retailers'. Therefore, South African small business retailers face competition on different fronts as their survival is threatened.

\section{Business intervention models}

According to Teece (2010):

$$
\begin{aligned}
& \text {... a good business model yields value propositions that are } \\
& \text { compelling to customers, achieves advantageous cost and risk } \\
& \text { structures, and enables significant value capture by the business } \\
& \text { that generates and delivers products and services. (p. 174) }
\end{aligned}
$$

Business models are a product of strategy; they are related but different concepts, as strategy is more of a contingent plan about what business model to use (Casadesus-Masanell \& Ricart 2010). Casadesus-Masanell and Ricart (2010:204) further noted that 'strategy entails designing business models (and redesigning them as contingencies occur) to allow the organisation to reach its goals. Business models are reflections of the realized strategy'. Baden-Fuller and Morgan (2010:167) also argued that 'business models have a multivalent character as models. They can be found as exemplary role models that might be copied or presented as nutshell descriptions of a business organisation'. However, business intervention models are business models that are a product of a previous model that have to be redesigned, and redesigning 
a model correctly requires a proper diagnosis of the previous models, understanding their failures and avoiding them when implementing the new model (Teece 2010).

When a model is created and implemented, it requires continuous evaluation to keep it viable as it will require interventions from time to time.

Teece (2010:174) noted that 'superior technology and products, excellent people, and good governance and leadership are unlikely to produce sustainable profitability if business model configuration is not properly adapted to the competitive environment'.

A successful model is one that is difficult for the competitor to replicate, but successful business models do get replicated at some point (Teece 2010).

\section{Research design and methodology}

The study employed a cross-sectional design and employed a quantitative research methodology.

\section{Location of the study}

The two specific townships in Cape Town - Delft and Eindhoven - were selected as the setting for this study. These two townships were chosen for this study as data were available on the number of the traders operating in these townships.

\section{The population of this study}

The population of this study comprised all the migrant and local small business retailers trading in Delft and Eindhoven.

\section{The sample of the study}

The sample of the study obtained using the simple random sampling technique comprised 75 migrant and 55 local small business retailers. This sample size was targeted based on suggestions provided by Sekaran and Bougi (2016).

\section{Research instrument}

A questionnaire comprising closed-ended questions was the research instrument used to collect data. The questionnaire was administered by the researcher with the help of two research assistants, and it aimed to establish the status quo of the traders regarding their competitiveness, skills and capabilities among other things.

\section{Data analysis}

Data analysis begins with data relevancy, that is, the variables and data must be problem specific. The researcher cannot draw a useful conclusion from variables and data that are not relevant to the research objectives (Wenger 2007). In this study, the researcher aligned all the questions in the questionnaire to a specific objective and then grouped the questions according to objectives to avoid any irrelevant data. The raw data collected were analysed, they then became relevant for the formulation of the recommendations emanating from this study. In this study SPSS, a computer software statistical package was used to analyse the quantitative data.

\section{Validity and reliability}

The validity and reliability strategies for the quantitative research components include applied sampling processes, reports on the number of respondents and non-respondents, descriptive analysis of all data and reports on statistical significance testing (Creswell 2015). For this study, a sampling frame has been carefully chosen and a representative sample selected to make sure that the study is valid, reliable and generalisable.

\section{Ethical consideration}

The University of KwaZulu-Natal (UKZN) has its own code of ethics like other academic institutions of higher learning. The researcher adhered to all codes of ethics as stipulated by the university. Among other things, the code of ethics covers matters relating to confidentiality, anonymity and the ability of the respondents to withdraw at any time during the study without any negative implications. In this study, the researcher applied and was granted ethical clearance from the UKZN research office. The researcher issued consent forms to each respondent.

\section{Discussion}

The study looked at competitive factors that distinguish small retailers of foreign origin from the South African small retailers. The factors included the level of education, the number of years the retailer has been in business, buying patterns of the two groups of traders and the status of trading space (whether it is owned or rented).

\section{Education level of trader groups}

Table 1 indicates that $61.3 \%$ of South African traders have education up to grade 12 . While this is also true for foreign national traders (61.8\%), South African traders have some tertiary qualification as well, including bachelor's degrees (5.3\%) and diplomas (8\%). The level of education is important as a form of literacy assessment (financial literacy included). Most traders, both local and foreign nationals, have the same education level, of matric (Grade 12). However, with regard to education, local traders have a competitive edge compared to local foreign national traders. One of the constraints facing small businesses in South Africa is the lack of entrepreneurship education in schools (Xheneti \& Bartlett 2012).

\section{Business experience of trader groups}

Table 2 indicates that in relation to South African traders, $34.5 \%$ have been trading for less than 3 years in the area, and $30.9 \%$ have been trading between 3 and 5 years in the area, 
meaning that the majority (65.4\%) of South African traders have a trading experience of less than 6 years. In relation to foreign traders, $53.3 \%$ have been trading for less than 3 years in the area, and $30.7 \%$ have between been trading between 3 and 5 years in the area, meaning that the majority $(84 \%)$ of foreign traders have less than 6 years of trading experience.

Furthermore, Table 2 indicates that $18.20 \%$ of the South African traders have been trading in the area for more than 10 years, whereas only $5.3 \%$ of the foreign traders have been in the area for more than 10 years. Table 2 shows that none of the foreign national traders have more than 15 years of trading experience in the area. This shows that the local traders have been trading in the township environments for longer periods compared to foreign national traders. However, the higher rate of new entrants among foreign national traders shows that they will become a majority in the township retailing, slowly ousting the local traders. Porter (2008:80) noted that, 'New entrants to an industry bring new capacity and a desire to gain market share that puts pressure on prices, costs, and the rate of investment necessary to compete'.

\section{Buying patterns of trader groups}

Table 3 indicates that in relation to South African traders, the majority (52.7\%) prefer buying stock in bulk. In relation to foreign traders, the majority (57.3\%) do not prefer buying stock in bulk. Table 3 also indicates that a relatively high

TABLE 1: The education level of traders.

\begin{tabular}{llcccc}
\hline Traders & Level of education & Frequency & $\mathbf{\%}$ & $\begin{array}{c}\text { Valid } \\
\mathbf{\%}\end{array}$ & $\begin{array}{c}\text { Cumulative } \\
\mathbf{\%}\end{array}$ \\
\hline Foreign & Bachelor's degree or higher & 0 & 0.0 & 0.0 & 0.0 \\
national & Diploma & 0 & 0.0 & 0.0 & 0.0 \\
traders & Grade 12 & 34 & 61.8 & 61.8 & 61.8 \\
& Grade 7 & 3 & 5.5 & 5.5 & 67.3 \\
& Grade 9 & 18 & 32.7 & 32.7 & 100.0 \\
& Total & 55 & 100.0 & 100.0 & - \\
South African & Bachelor's degree or higher & 4 & 5.3 & 5.3 & 5.3 \\
traders & Diploma & 6 & 8.0 & 8.0 & 13.3 \\
& Grade 12 & 36 & 48.0 & 48.0 & 61.3 \\
& Grade 7 & 16 & 21.3 & 21.3 & 82.7 \\
& Grade 9 & 13 & 17.3 & 17.3 & 100.0 \\
& Total & 75 & 100.0 & 100.0 & - \\
\hline
\end{tabular}

TABLE 2: The number of years the business has been in operation.

\begin{tabular}{llcccc}
\hline Traders & $\begin{array}{l}\text { How many years of business } \\
\text { experience do you have? }\end{array}$ & Frequency & $\begin{array}{c}\mathbf{\%} \\
\mathbf{\%}\end{array}$ & $\begin{array}{c}\text { Valid } \\
\mathbf{\%}\end{array}$ \\
\hline Foreign & Less than 3 years & 40 & 53.3 & 53.3 & 53.3 \\
national & Between 3 and 5 years & 23 & 30.7 & 30.7 & 84.0 \\
traders & Between 6 and 10 years & 8 & 10.7 & 10.7 & 94.7 \\
& Between 11 and 15 years & 4 & 5.3 & 5.3 & 100.0 \\
& Over 15 years & 0 & 0.0 & 0.0 & 0.0 \\
& Total & 75 & 100.0 & 100.0 & - \\
South African & Less than 3 years & 19 & 34.5 & 34.5 & 34.5 \\
traders & Between 3 and 5 years & 17 & 30.9 & 30.9 & 65.4 \\
& Between 6 and 10 years & 9 & 16.4 & 16.4 & 81.8 \\
& Between 11 and 15 years & 6 & 10.9 & 10.9 & 92.7 \\
& Over 15 years & 4 & 7.3 & 7.3 & 100.0 \\
& Total & 55 & 100.0 & 100.0 & - \\
\hline
\end{tabular}

percentage of South African traders do not prefer to buy stock in bulks, while a high percentage of foreign national traders prefer to buy stock in bulk. Bulk buying is a costsaving method for retailers, but it also ties the retailer's cash flow on the stock item bought in bulk, meaning that when there is a need to buy other out-of-stock items, the retailer might experience a cash crunch.

Table 4 indicates that in relation to South African traders, $18.2 \%$ order their stock on a daily basis, and the majority $(65.5 \%)$ prefer ordering stock on a weekly basis. In relation to foreign traders, $17.3 \%$ order their stock on a daily basis, and the majority $(65.3 \%)$ prefer ordering stock on a weekly basis. Table 4 indicates that South African traders and foreign national traders are mimicking each other on the ordering patterns.

\section{Operating space status}

Table 5 indicates that in relation to South African traders, $56.4 \%$ are full owners of their small business retail stores, and $14.5 \%$ are owner managers, meaning that the majority $(70.9 \%)$ of South African traders have a direct ownership of their small business retail stores. In relation to foreign traders, $56.0 \%$ are full owners of their small business retail stores, and $20 \%$ are owner managers, meaning that the majority $(70.6 \%)$ of foreign national traders have a direct ownership of their small business retail stores. The study revealed that for both local and foreign national traders, there are very few stores that are not directly owned by the traders (Table 5).

Table 6 indicates that in relation to foreign national traders, the majority $(65.5 \%)$ fully own their small retail stores. In relation to South African traders, $62.7 \%$ rent their stores from South African locals. This reveals that the majority of foreign national traders do not pay rent as they own their stores. Furthermore, Table 6 revealed that $37.3 \%$ of

TABLE 3: Data depicting whether or not traders buy stock in bulk.

\begin{tabular}{llcccc}
\hline Traders & $\begin{array}{l}\text { Do you buy } \\
\text { in bulk? }\end{array}$ & Frequency & $\begin{array}{c}\text { \% } \\
\text { Valid } \\
\mathbf{\%}\end{array}$ & $\begin{array}{c}\text { Cumulative } \\
\mathbf{\%}\end{array}$ \\
\hline Foreign national & No & 43 & 57.3 & 57.3 & 57.3 \\
& Yes & 32 & 42.7 & 42.7 & 100.0 \\
& Total & 75 & 100.0 & 100.0 & - \\
South African national & No & 26 & 47.3 & 47.3 & 47.3 \\
& Yes & 29 & 52.7 & 52.7 & 100.0 \\
& Total & 55 & 100.0 & 100.0 & - \\
\hline
\end{tabular}

TABLE 4: The number of times traders order stock.

\begin{tabular}{|c|c|c|c|c|c|}
\hline Traders & $\begin{array}{l}\text { How often do } \\
\text { you stock? }\end{array}$ & Frequency & $\%$ & $\begin{array}{c}\text { Valid } \\
\%\end{array}$ & $\begin{array}{c}\text { Cumulative } \\
\%\end{array}$ \\
\hline \multirow[t]{5}{*}{ Foreign national } & Bi-monthly & 4 & 5.3 & 5.3 & 5.3 \\
\hline & Daily & 13 & 17.3 & 17.3 & 22.7 \\
\hline & Monthly & 9 & 12.0 & 12.0 & 34.7 \\
\hline & Weekly & 49 & 65.3 & 65.3 & 100.0 \\
\hline & Total & 75 & 100.0 & 100.0 & - \\
\hline \multirow[t]{5}{*}{ South African national } & Bi-monthly & 4 & 7.3 & 7.3 & 7.3 \\
\hline & Daily & 10 & 18.2 & 18.2 & 25.5 \\
\hline & Monthly & 5 & 9.1 & 9.1 & 34.5 \\
\hline & Weekly & 36 & 65.5 & 65.5 & 100.0 \\
\hline & Total & 55 & 100.0 & 100.0 & - \\
\hline
\end{tabular}


TABLE 5: The management format of the trader's store of foreign national traders.

\begin{tabular}{llcccc}
\hline Traders & Business ownership & Frequency & $\mathbf{\%}$ & $\begin{array}{c}\text { Valid } \\
\mathbf{\%}\end{array}$ & $\begin{array}{c}\text { Cumulative } \\
\mathbf{\%}\end{array}$ \\
\hline Foreign & Full owner & 42 & 56.0 & 56.0 & 56.0 \\
national & Manager & 3 & 4.0 & 4.0 & 60.0 \\
& Owner manager & 15 & 20.0 & 20.0 & 80.0 \\
& Part owner & 15 & 20.0 & 20.0 & 100.0 \\
& Total & 75 & 100.0 & 100.0 & - \\
South African & Full owner & 31 & 56.4 & 56.4 & 56.4 \\
national & Manager & 1 & 1.8 & 1.8 & 58.2 \\
& Own manager & 8 & 14.5 & 14.5 & 72.7 \\
& Part owner & 15 & 27.3 & 27.3 & 100.0 \\
& Total & 55 & 100.0 & 100.0 & - \\
\hline
\end{tabular}

TABLE 6: Data depicting whether traders own or rent their store site.

\begin{tabular}{llcccc}
\hline Traders & $\begin{array}{l}\text { Own or rental } \\
\text { premises }\end{array}$ & Frequency & $\mathbf{\%}$ & $\begin{array}{c}\text { Valid } \\
\mathbf{\%}\end{array}$ & $\begin{array}{c}\text { Cumulative } \\
\mathbf{\%}\end{array}$ \\
\hline Foreign & Own & 36 & 65.5 & 65.5 & 65.5 \\
national & Rent & 19 & 34.5 & 34.5 & 100.0 \\
& Total & 55 & 100.0 & 100.0 & - \\
South African & Own & 28 & 37.3 & 37.3 & 37.3 \\
national & Rent & 47 & 62.7 & 62.7 & 100.0 \\
& Total & 75 & 100.0 & 100.0 & - \\
\hline
\end{tabular}

TABLE 7: Cross-tabulation between the variables: 'level of education' and 'Trading hours'.

\begin{tabular}{llcc}
\hline Variable & Measurement & Level of education & Trading hours \\
\hline Level of education & Pearson correlation & 1.00 & $-0.09 *$ \\
& Sig. (2-tailed) & & 0.00 \\
& $N$ & 55.00 & 55.00 \\
Trading hours & Pearson correlation & $-0.09 *$ & 1.00 \\
& Sig. (2-tailed) & 0.00 & - \\
& $N$ & 55.00 & 55.00 \\
\hline
\end{tabular}

Sig., significance.

*, Correlation is significant at the 0.01 level (2-tailed).

South African traders own their stores and therefore do not pay any rental. Rent is one of the high-expense items in the income statement of retailers, and a saving on rental can ease the cash flow of the trader.

\section{Comparative factors (cross tabulations) - Local traders}

Table 7 shows that the two variables have a statistical significance level of 0.000 . This significance level is lower than the conventional cut-off level of 0.05 ; therefore, the two variables are statistically significant. This also means that there is likely to be a relationship between the two variables. $\mathrm{N}$ reflects the number of respondents who answered the two questions. All the respondents out of a total of 55 respondents indicated both their 'level of education' and their 'trading hours'.

Table 8 shows that the two variables have a statistical significance level of 0.000 . This significance level is lower than the conventional cut-off level of 0.05; therefore, the two variables are statistically significant. This also means that there is likely to be a relationship between the two variables. $\mathrm{N}$ reflects the number of respondents who answered the two questions. All the respondents out of a total of 55 respondents indicated both their 'trading hours' and their 'turnover'.
TABLE 8: Cross-tabulation between the variables: 'Trading hours' and 'Turnover'.

\begin{tabular}{llcc}
\hline Variable & Measurement & Level of education & Trading hours \\
\hline Trading hours & Pearson correlation & 1.00 & $-0.0038^{*}$ \\
& Sig. (2-tailed) & - & 0.00 \\
& $\mathrm{~N}$ & 55.00 & 55.00 \\
Turnover & Pearson correlation & $-0.0038^{*}$ & 1.00 \\
& Sig. (2-tailed) & 0.00 & - \\
& $\mathrm{N}$ & 55.00 & 55.00 \\
\hline
\end{tabular}

Sig., significance.

*, Correlation is significant at the 0.01 level (2-tailed).

TABLE 9: Cross-tabulation between the variables: 'Trading hours' and 'Number of customers'.

\begin{tabular}{llcc}
\hline Variable & Measurement & Trading hours & Number of customers \\
\hline Trading hours & Pearson correlation & 1.00 & $0.19^{*}$ \\
& Sig. (2-tailed) & - & 0.00 \\
& $N$ & 55.00 & 55.00 \\
Number of & Pearson correlation & $0.19^{*}$ & 1.00 \\
customers & Sig. (2-tailed) & 0.00 & - \\
& $N$ & 55.00 & 55.00 \\
\hline
\end{tabular}

Sig., significance.

*, Correlation is significant at the 0.01 level (2-tailed).

TABLE 10: Cross-tabulation between the variables: 'Level of education' and 'Years of experience'.

\begin{tabular}{llcc}
\hline Variable & Measurement & Level of education & Years of experience \\
\hline Level of education & Pearson correlation & 1.00 & $0.18^{*}$ \\
& Sig. (2-tailed) & - & 0.63 \\
& $N$ & 75.00 & 75.00 \\
Years of experience & Pearson correlation & $0.18^{*}$ & 1.00 \\
& Sig. (2-tailed) & 0.63 & - \\
& $N$ & 75.00 & 75.00 \\
\hline
\end{tabular}

Sig., significance.

*, Correlation is significant at the 0.01 level (2-tailed).

Table 9 shows that the two variables have a statistical significance level of 0.00 . This significance level is lower than the conventional cut-off level of 0.05 ; therefore, the two variables are statistically significant. This also means that there is likely to be a relationship between the two variables.

$\mathrm{N}$ reflects the number of respondents who answered the two questions. All the respondents out of a total of 55 respondents indicated both their 'trading hours' and their 'number of customers'.

\section{Comparative factors (cross tabulations) - Foreign national traders}

Table 10 shows that the two variables have a statistical significance level of 0.63 . This significance level is higher than the conventional cut-off level of 0.05 ; therefore, the two variables are not statistically significant. This also means that there is not a likelihood of a relationship between the two variables. $\mathrm{N}$ reflects the number of respondents who answered the two questions. All the respondents out of a total of 75 respondents indicated both their 'level of education' and their 'years of experience'.

Table 11 shows that the two variables have a statistical significance level of 0.000 . This significance level is lower than the conventional cut-off level of 0.05 ; therefore; the two variables are statistically significant. This also means 
TABLE 11: Cross-tabulation between the variables: 'Level of education' and 'Years of experience'.

\begin{tabular}{llcc}
\hline Variable & Measurement & Level of education & Trading hours \\
\hline Level of education & Pearson correlation & 1.00 & $-0.24^{*}$ \\
& Sig. (2-tailed) & - & 0.00 \\
& $N$ & 75.00 & 75.00 \\
Trading hours & Pearson correlation & $-0.24^{*}$ & 1.00 \\
& Sig. (2-tailed) & 0.00 & - \\
& $N$ & 75.00 & 75.00 \\
\hline
\end{tabular}

Sig., significance.

*, Correlation is significant at the 0.01 level (2-tailed).

TABLE 12: Cross-tabulation between the variables: 'Level of education' and 'Years of experience'.

\begin{tabular}{llcc}
\hline Variable & Measurement & Trading hours & Turnover \\
\hline Trading hours & Pearson correlation & 1.00 & $0.10^{*}$ \\
& Sig. (2-tailed) & - & 0.00 \\
& $N$ & 75.00 & 75.00 \\
Turnover & Pearson correlation & $0.10^{*}$ & 1.00 \\
& Sig. (2-tailed) & 0.00 & - \\
& $N$ & 75.00 & 75.00 \\
\hline
\end{tabular}

Sig., significance.

*, Correlation is significant at the 0.01 level (2-tailed).

that there is a likelihood of a relationship between the two variables.

$\mathrm{N}$ reflects the number of respondents who answered the two questions. All the respondents out of a total of 75 respondents indicated both their 'level of education' and their 'trading hours'.

Table 12 shows that the two variables have a statistical significance level of 0.000 . This significance level is lower than the conventional cut-off level of 0.05 ; therefore; the two variables are statistically significant.

This also means that there is a likelihood of a relationship between the two variables.

$\mathrm{N}$ reflects the number of respondents who answered the two questions. All the respondents out of a total of 75 respondents indicated both their 'trading hours' and their 'turnover'.

Table 13 shows that the two variables have a statistical significance level of 0.02 . This significance level is lower than the conventional cut-off level of 0.05 ; therefore; the two variables are statistically significant. This also means that there is a likelihood of a relationship between the two variables.

$\mathrm{N}$ reflects the number of respondents who answered the two questions. All the respondents out of a total of 75 respondents indicated both their 'trading hours' and their 'number of customers'.

\section{Proposed small business intervention framework}

Charman, Peterson and Piper (2012) noted that:

... in financial terms, the majority of spaza shops owned by foreign nationals equate to small size enterprises rather than
TABLE 13: Cross-tabulation between the variables: 'Level of education' and 'Years of experience'.

\begin{tabular}{llcc}
\hline Variable & Measurement & Trading hours & Number of customers \\
\hline Trading hours & Pearson correlation & 1.00 & $0.11^{*}$ \\
& Sig. (2-tailed) & - & 0.02 \\
& $N$ & 75.00 & 75.00 \\
Number of & Pearson correlation & $0.11^{*}$ & 1.00 \\
customers & Sig. (2-tailed) & 0.02 & - \\
& $N$ & 75.00 & 75.00 \\
\hline
\end{tabular}

Sig., significance.

*, Correlation is significant at the 0.01 level (2-tailed).

micro-enterprises, as the scale of their operation and turnover is significantly greater than that of the average South African spaza. (p. 66)

Furthermore, the authors argue that local small business retailers can be classified as survivalist entrepreneurs, as they run their small businesses on their individual capacities without collaborating with each other. However, Herrington (2014:72) stated that, 'South Africa's rate of entrepreneurial activity is very low for a developing nation, a mere quarter of that seen in other sub-Saharan African countries'. This assertion suggests that any suggested business intervention framework should be aimed at entrepreneurial activity of the South African small business retailer.

The business intervention framework depicted in Figure 1 can be used to assist small business retailers in the township retailing environments.

The business intervention framework provided in Figure 1 is based on the findings of this study. Government intervention is the critical element for the development of South African small retailers. This model suggests training and incubation of local traders (both potential traders and current traders who need access to funding from government). However, the training suggested in this framework must be targeted training of small retailers on various aspects of managing a small retail business in the South African township environment. Through the training programme, the traders will have an opportunity to undergo a period of incubation. On the successful completion of the incubation programme, the framework recommends that the trader should also undergo mentorship where the trader will benefit by getting new business knowledge and capacity building from a mentor. The benefits of having a mentor is that the trader might also be introduced to new business suppliers and networks known to the mentor.

The framework suggests a deliberate formation of formal business networks for small business retailers initiated by the South African government's Department of Small Business Development. The network will be responsible for information sharing and exploration of further business opportunities among the small business retail community in township environments.

The framework suggests that the Wholesale and Retail Sector Training Authority (W\&R SETA) should appoint programme 


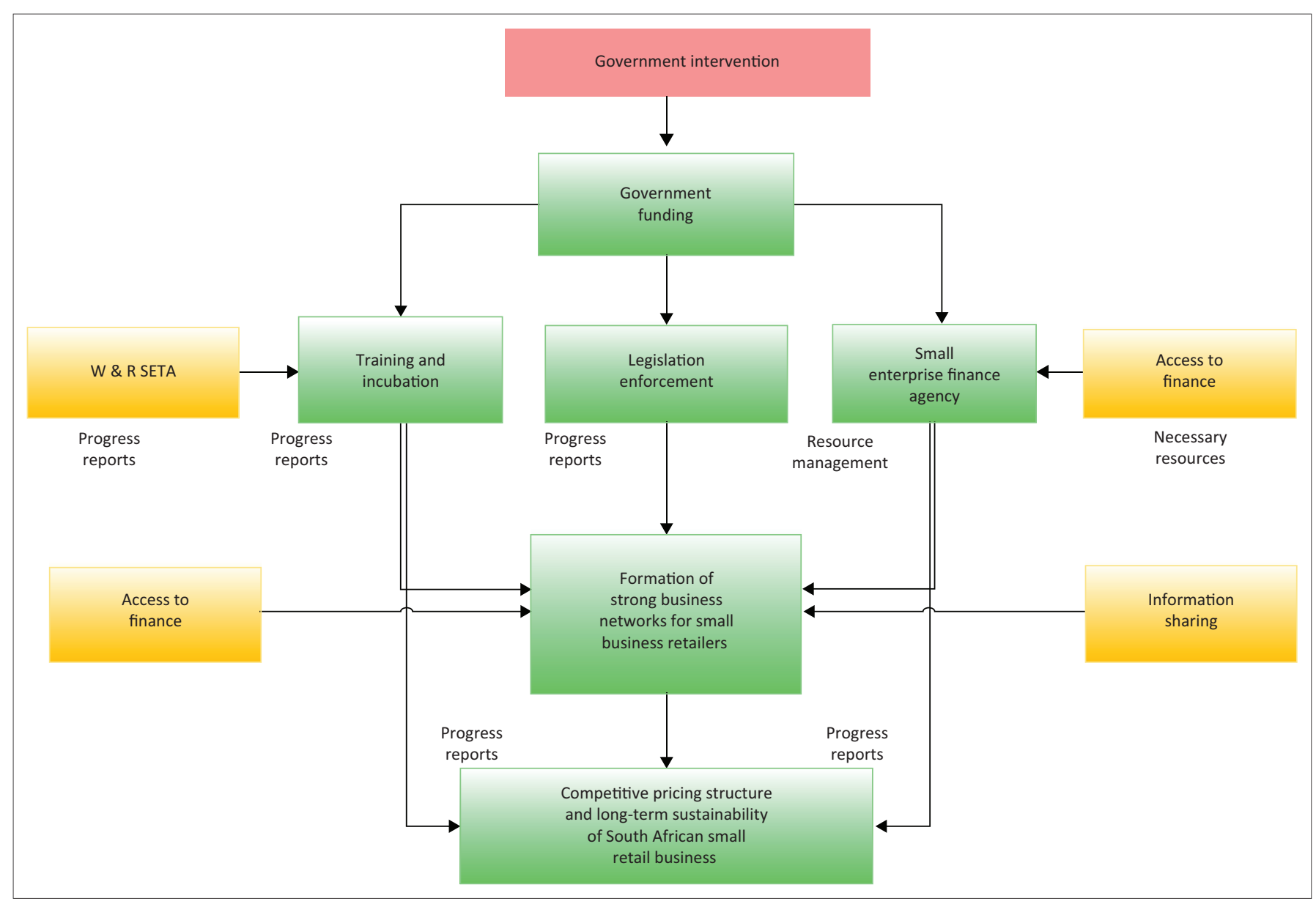

W, wholesale; R SETA, retail sector education \& training authority.

FIGURE 1: Recommended business intervention framework.

managers to guide the small retailers through the various stages proposed in this framework. It is recommended that at the incubation stage, the traders are provided with shipping containers that have been custom made to suite retail businesses, as such structures have proven to protect retailers against criminal elements. Furthermore, it is recommended that such containers be equipped with the storage capacity that the traders urgently need.

\section{Recommendations}

It is recommended that a pre-programmed computerised system with inventory delivery and control is supplied to small retailers, as such a system eliminates several of the problems and shortcomings that these small businesses encounter. The pre-programmed computerised system will make it possible to buy stock, and the amount owed for the stock is subtracted and directly paid to the supplier. This ensures sustainability of the business.

It is also recommended that the South African small retailers must consider alternative buying and delivery models such as a centralised buying model so that the required stock is delivered to them instead of them leaving their premises every time they have to replenish stock. This could save them time and transportation costs.

\section{Conclusion}

The study identified various areas of challenge for the South African small business retailers, such as a lack of adequate education level, a lower rate of new entrants among South African small business retailers as compared to their foreign national counterparts and poor stock management systems. Based on the identified challenges, a business intervention model for the South African trader is suggested in this study. The implementation of this model envisages an outcome whereby local traders can improve their competitiveness through competitive pricing strategies, which can then sustain and grow their small enterprises into medium enterprises. The success of the South African small business retailers will have a positive impact on the efforts to reduce unemployment in South Africa. Through the business intervention model discussed, the study suggests that the South African government development agencies have a funding model targeted specifically at small business retailers. Through government funding, the W\&R SETA, as suggested in the proposed business intervention model, needs to be the custodian of the training for small retailers consistent with their mandate.

\section{Acknowledgements}

The authors would like to thank the Cape Peninsula University of Technology for the support it has given to 
Mr M. Malgas in attending the conference on Retailing in the United Kingdom. The conference provided invaluable information that was used in putting together this article.

\section{Competing interests}

The authors declare that they have no financial or personal relationships that may have inappropriately influenced them in writing this article.

\section{Authors' contributions}

M.M. and W.B.Z. collaborated in the conception and design of the research. M.M. collected, analysed and interpreted the data, and drafted the manuscript. W.B.Z. critically revised the manuscript and approved the final version to be published.

\section{Funding}

This research received no specific grant from any funding agency in the public, commercial or not-for-profit sectors.

\section{Data availability statement}

Data sharing is applicable to this article as new data were created and analysed. Data can be obtained from the authors upon request.

\section{Disclaimer}

The views and opinions expressed in this article are those of the authors and do not necessarily reflect the official policy or position of any affiliated agency of the authors.

\section{References}

Adisa, T.A., Abdulraheem, I. \& Mordi, C., 2014, 'The characteristics and challenges of small businesses in Africa: An exploratory study of Nigerian Business Owners', Small businesses in Africa: An explora
Economic Insights III (LXVI)(4), 1-14.

Antonites, A.J. \& Kliphuis, W., 2011, 'An exploratory study on the potential value add of social networking to the entrepreneurial process', The South African Journal of Entrepreneurship and Small Business Management 4(1), 1-23.

Ardyan, E., 2016, 'Market sensing capability and SMEs performance: The mediating role of product innovativeness success market sensing capability and SMEs performance: The mediating role of product innovativeness success', DLSU Business and Economics Review 2(January), 79-97.
Baden-Fuller, C. \& Morgan, M.S., 2010, 'Business models as models', Long Range Planning 43(2-3), 156-171. https://doi.org/10.1016/j.Irp.2010.02.005

Battersby, J., Marshak, M. \& Mngqibisa, N., 2017, 'Mapping in the invisible: The informal food Economy of Cape Town, South Africa', African Food Security Urban Network 24(January), 1-47. https://doi.org/10.2307/j.ctvh8r2fq

Brijlal, P. \& Jere, A.K., 2019, 'Identifying and exploiting economic opportunities: The case of unemployed women in Khayelitsha Township, Cape Town', African Journal of Business and Economic Research 14(2), 5-23. https://doi.org/10.31920/17504562/2019/14n2a 1

Cant, M. \& Wiid, J., 2013, 'Establishing the challenges affecting South African SMEs', International Business and Economics Research Journal 12(6), 707-716. https:// doi.org/10.19030/iber.v12i6.7869

Casadesus-Masanell, R. \& Ricart, J.E., 2010, 'From strategy to business models and onto tactics', Long Range Planning 43(2-3), 195-215. https://doi.org/10.1016/j. Irp.2010.01.004

Creswell, J.W., 2015, A concise introduction to mixed methods research, Sage, Thousand Oaks, CA.

Danish, R.Q., Asghar, J., Ahmad, Z. \& Ali, H.F., 2019, 'Factors affecting “entrepreneurial culture": The mediating role of creativity', Journal of Innovation and Entrepreneurship 8(14), 2-12. https://doi.org/10.1186/s13731-019-0108-9

Döckel, J.A. \& Ligthelm, A.A., 2005, 'Factors responsible for the growth of small business', South African Journal of Economic and Management Sciences 8(1) 54-62. https://doi.org/10.4102/sajems.v8i1.1283

Herrington, M., 2014, 'Entrepreneurship in South Africa: GEM impact on policy', Global Entrepreneurship Monitor (GEM), 2014 global report, pp. 1-115.

Herrington, M., Kew, P. \& Mwanga, A., 2017, 'South Africa Report 2016/2017, can small businesses survive in South Africa', Global Entrepreneurship Monitor (GEM) 2016(1), 1-64.

Liedeman, R., 2013, 'Understanding the internal dynamics and organisation of Spaza shop operators', Master's Thesis, UWC.

Ligthelm, A.A., 2003, 'Informal retail structures in South Africa: An exploratory study 1', Southern African Business Review 7(1), 54-63.

Ligthelm, A.A., 2008, 'The impact of shopping mall development on small township retailers', South African Journal of Economic and Management Sciences 11(1), 37-53. https://doi.org/10.4102/sajems.v11i1.376

Ntema, L. \& Marais, L., 2010, 'Trade is in our blood: Reflections on trends and conflicts in township trade', CDS Research Report, LED and SMME Development 2010(1), $1-54$.

Porter, M.E., 2008, 'The five competitive forces that shape strategy', Harvard Business Review, January 2008, 78-94.

Rolfe, R., Woodward, D., Ligthelm, A. \& Guimarães, P., 2010, 'The viability of informal micro-enterprise in South Africa', Whitman School of Management Entrepreneurship in Africa conference, Syracuse University, Syracuse, New York, April 1-3, 2010

Sekaran, U. \& Bougie, R., 2016, Research methods for business: A skill building approach, 5th edn., Hermitage, New York.

Strydom, J., 2015, 'David against Goliath David: Predicting the survival of formal small businesses in Soweto', International Business and Economics Research Journal 14(3), 463-476. https://doi.org/10.19030/iber.v14i3.9210

Teece, D.J., 2010, 'Business models, business strategy and innovation', Long Range Planning 43(2-3), 172-194. https://doi.org/10.1016/j.Irp.2009.07.003

Wenger, T., 2007, Applied business statistics, Juta, Cape Town.

Xheneti, M. \& Bartlett, W., 2012, 'Institutional constraints and SME growth in postcommunist Albania', Journal of Small Business and Enterprise Development 19(4) 607-626. https://doi.org/10.1108/14626001211277424 